\title{
In Situ Surface-Directed Assembly of 2D Metal Nanoplatelets for Drug-Free Treatment of Antibiotic-Resistant Bacteria
}

Parinaz Fathi, ${ }^{a}$ Ayman Roslend, ${ }^{a}$ Maha Alafeef, ${ }^{a}$ Mandy B. Esch, ${ }^{b}$ and Dipanjan Pan..${ }^{a, c *}$

${ }^{a}$ Departments of Bioengineering, Materials Science and Engineering, and Beckman Institute, University of Illinois at Urbana-Champaign, Urbana, Illinois 61801, U.S.

${ }^{\mathrm{b} B i o m e d i c a l}$ Technologies Group, Microsystems and Nanotechnology Division, Physical Measurement Laboratory, National Institute of Standards and Technology, Gaithersburg, Maryland 20899, United States

${ }^{c}$ Departments of Diagnostic Radiology Nuclear Medicine, Pediatrics, and Chemical and Biomolecular Engineering, University of Maryland School of Medicine and University of Maryland Baltimore County, Baltimore, MD 21201, U.S.

*Corresponding author: Professor Dipanjan Pan (dipanjan@som.umaryland.edu)

\section{ABSTRACT}

The development of antibiotic resistance among bacterial strains is a major global public health concern. To address this, drug-free antibacterial approaches are needed. Hightouch surfaces in particular can serve as a means for the spread of bacteria and other pathogens from one infected person to another. Copper surfaces have long been known for their antibacterial properties. To further enhance the surface's antibacterial properties, we used a one-step surface modification technique to assemble 2D copper chloride nanoplatelets directly onto copper surfaces such as copper tape, transmission electron microscopy (TEM) grids, electrodes, and granules. The nanoplatelets were formed using copper ions from the copper surfaces, enabling their direct assembly onto these surfaces in a one-step process that does not require separate nanoparticle synthesis. The synthesis of the nanoplatelets was confirmed with TEM, scanning electron microscopy, energy dispersive spectroscopy (EDS), x-ray diffraction (XRD), and Fourier transform infrared spectroscopy (FT-IR). Antibacterial properties of the surfaces with copper 
chloride nanoplatelets were demonstrated in multi-drug-resistant (MDR) E. coli. The presence of copper chloride nanoplatelets on the surface led to a marked improvement in antibacterial properties compared to the untreated copper surfaces. Surfaces with copper chloride nanoplatelets affected bacterial cell morphology, prevented bacterial cell division, reduced their viability, damaged bacterial deoxyribonucleic acid (DNA), and altered protein expression. In particular, proteins corresponding to cell division, DNA division, and mediation of copper toxicity were down-regulated. This work presents a robust method to directly assemble copper chloride nanoplatelets onto any copper surface to imbue it with improved antibacterial properties. To demonstrate that our method of particle generation can be used with other metal surfaces, we also demonstrate the synthesis of other metal-derived nanoarchitectures on a variety of metal surfaces.

\section{INTRODUCTION}

Drug-resistant bacterial infections are a rising concern with increasing prescription of antibiotics. High-touch surfaces have been proven to contribute to pathogen spread. ${ }^{1}$ Attempts to provide surfaces with antibacterial properties often rely on the application of surface coatings. ${ }^{2}$ Nanomaterials have been successfully synthesized for use in a variety of applications in medicine ${ }^{3-14}$ including the detection and eradication of bacteria. ${ }^{15-22}$ Nanoparticle-based approaches to developing antibacterial surfaces typically rely on the synthesis of nanoparticles followed by their subsequent incorporation into polymer-based coatings that do not have inherent antibacterial properties.

The antibacterial properties of copper surfaces have long been known, and copper is used in a variety of medical devices including dental implants, intrauterine devices, and 
catheters. $^{23-28}$ The goal of this work was to further improve the antibacterial properties of copper surfaces by developing antibacterial coatings that could be assembled directly onto copper surfaces. Using a robust and simple synthesis process, copper chloride nanoplatelets were assembled onto a variety of copper surfaces (Figure 1). The synthesis was conducted by dropping a solution of dilute $\mathrm{HCl}$ or dilute $\mathrm{HCl}$ in combination with 2 2'-(ethylenedioxy)bis(ethylamine) directly onto the metal surface. The resulting nanoplatelets are referred to as $\mathrm{Cu} @ \mathrm{HCl} \mathrm{NP}$ and $\mathrm{Cu} @ \mathrm{HCl}-\mathrm{NH}_{2} \mathrm{NP}$, respectively. The physicochemical properties of the nanoplatelets were extensively characterized, and the improved antibacterial properties of the particle-covered surfaces were compared to those of untreated copper surfaces using data obtained with E. coli and Multi-drugresistant (MDR) E. coli. These model bacteria were selected because drug resistance in E. coli is of increasing concern. ${ }^{29-33}$

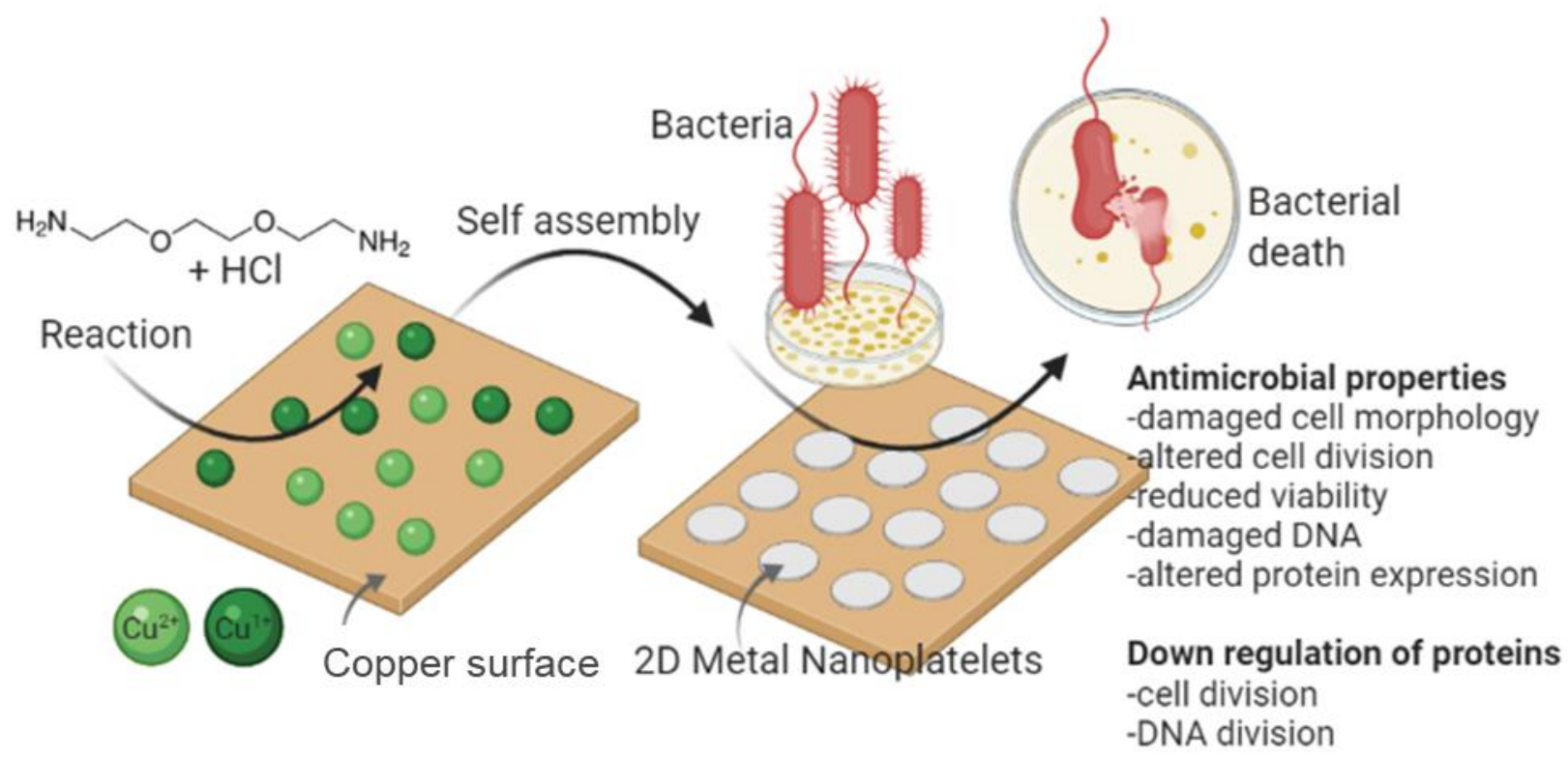

\section{In-Situ Metal-Directed Assembly of 2D Nanoplatelets for Drug-Free Treatment of Antibiotic-Resistant Bacteria}

Figure 1. Self-assembly of copper-derived nanoplatelets onto copper surfaces. A synthesis solution composed of dilute $\mathrm{HCl}$ or dilute $\mathrm{HCl}$ in combination with small amounts of 2 2'(ethylenedioxy)bis(ethylamine) is deposited onto a copper surface and allowed to dry. No copper is present in the synthesis solution itself. Upon deposition of the synthesis solution onto the copper surface, chlorine 
ions from the $\mathrm{HCl}$ couple with copper ions from the surface to form copper chloride crystals (copper nanoplatelets). The nanoplatelets exhibit improved antibacterial properties compared to the copper surfaces alone. The inclusion of 2 2'-(ethylenedioxy)bis(ethylamine) modifies nanoplatelet morphology.

\section{RESULTS AND DISCUSSION}

\section{Copper nanoplatelets were assembled directly on multiple copper surfaces}

The precursor solution for $\mathrm{Cu} @ \mathrm{HCl}$ NPs contained only dilute $\mathrm{HCl}$, while the precursor solution for $\mathrm{Cu} @ \mathrm{HCl}-\mathrm{NH}_{2} \mathrm{NPs}$ contained dilute $\mathrm{HCl}$ and a small amount of 2 2'-(ethylenedioxy)bis(ethylamine) (referred to as diamine). Full details of experimental procedures are provided in the Methods section. Deposition of the solutions onto the copper side of copper TEM grids led to the formation of nanoplatelets directly on the TEM grid surfaces. TEM imaging revealed the formation of $\mathrm{Cu} @ \mathrm{HCl}$ NPs with sizes of less than $100 \mathrm{~nm}$, in addition to the formation of nanoparticles with diameters less than $10 \mathrm{~nm}$

(Figure 2A). In contrast, $\mathrm{Cu} @ \mathrm{HCl}-\mathrm{NH}_{2}$ NPs exhibited larger sizes with widths of approximately $0.25 \mu \mathrm{m}$ to $1 \mu \mathrm{m}$. The rod-like structures in the TEM images provide a view of nanoplatelets with a vertical orientation, confirming that their thickness is in the nanometer range. Additionally, the thin size of the nanoplatelets is also confirmed by the slight reduction in transmission of electrons through areas with overlapping nanoplatelets. The difference in size between $\mathrm{Cu} @ \mathrm{HCl}$ NPs and Cu@HCI-NH2 NPs can be attributed to an effect of diamine on crystallization as the nanoplatelets are formed. The formation of the nanoplatelets on the copper TEM grids was further confirmed by scanning electron microscopy conducted on the TEM grids (Figure 2B, Figure S1). Some nanoplatelets have either moved from the copper portions of the TEM grid to the carbon surface, or have newly formed on the carbon surface from copper ions that have diffused into the solution from the copper surfaces. To confirm the composition of the nanoplatelets, 
energy dispersive spectroscopy (EDS) was conducted on $\mathrm{Cu} @ \mathrm{HCl}-\mathrm{NH}_{2} \mathrm{NPs}$ at various locations on the carbon portion of the TEM grid (Figure S2). EDS confirmed the presence of copper in these nanoplatelets, and also identified the presence of chlorine atoms, suggesting the nanoplatelets are likely composed of copper chloride. The presence of carbon and oxygen can be attributed to the carbon and oxygen atoms in the carbon grid coating, as well as the atoms in the diamine molecules.

(A)
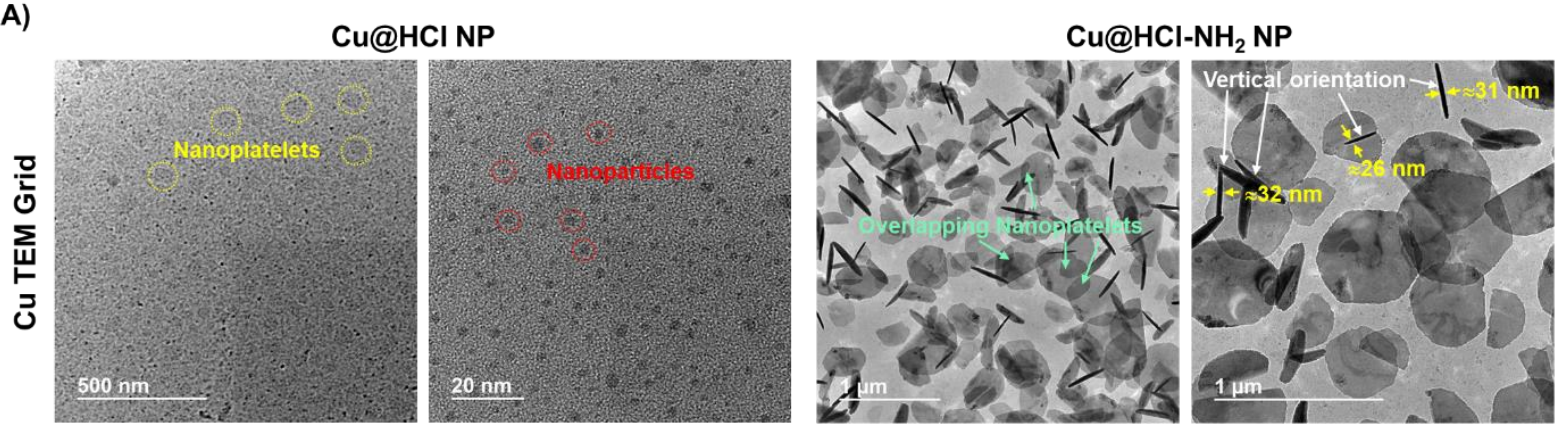

(B)
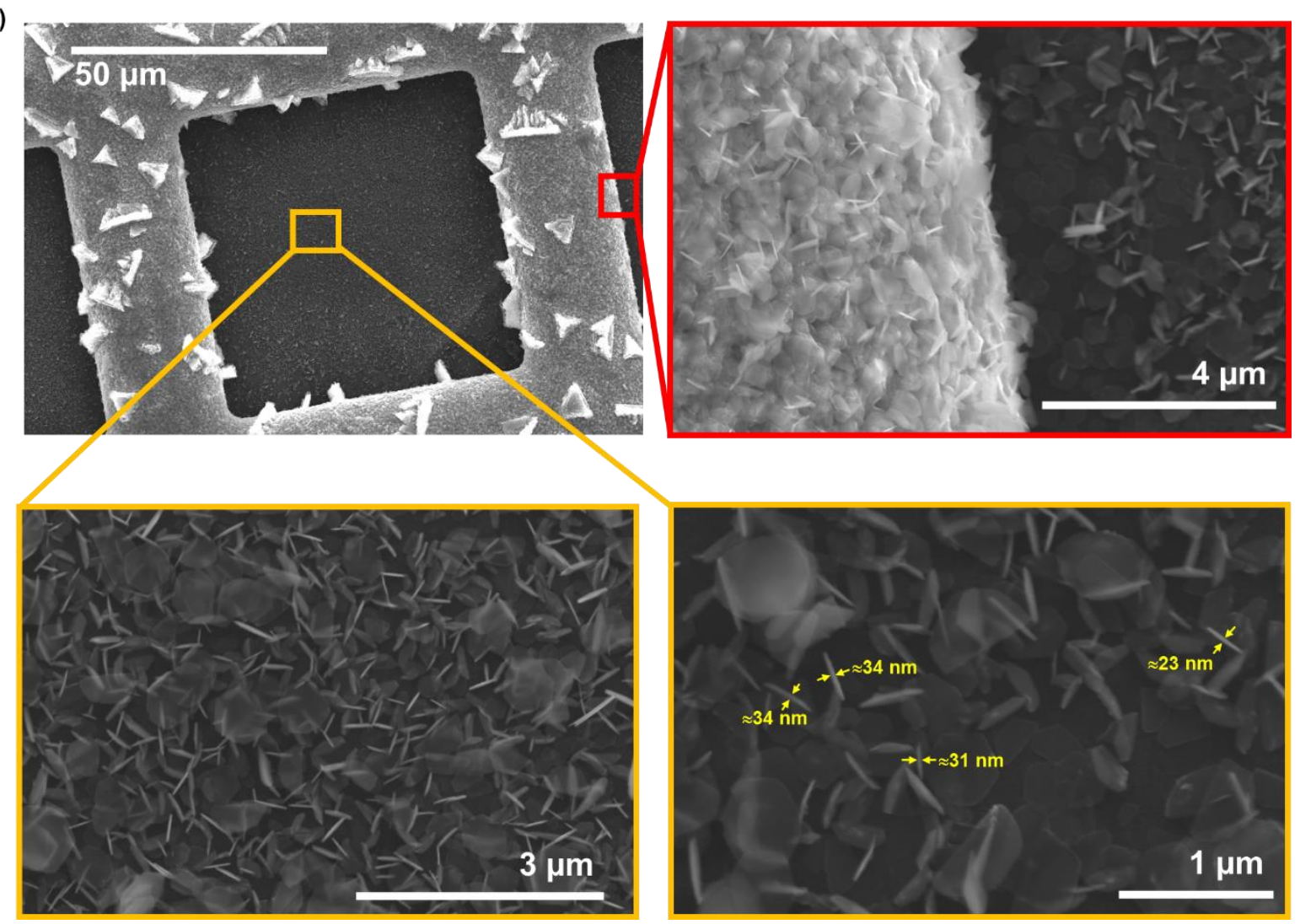

Figure 2. Copper chloride nanoplatelets formed on copper TEM grids. (A) TEM images of Cu@HCI NPs

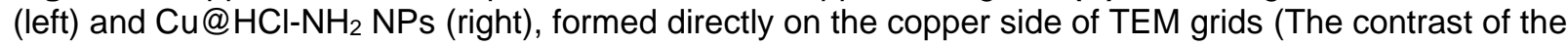


nanoplatelets is less than the contrast from the nanoparticles because the nanoplatelets are very thin). Nanostructures formed using the $\mathrm{HCl}$ solution alone include small nanoplatelets and nanoparticles, while the $\mathrm{HCl}$ and diamine solution results in the formation of hexagonal nanoplatelets. Rod-like structures are nanoplatelets that are oriented vertically rather than horizontally (B) SEM image of copper grid containing $\mathrm{Cu} \mathrm{HCl}-\mathrm{NH}_{2}$ NPs. Nanoplatelets are found both on the copper portion of the grid and on the carbon portion of the grid, indicating the nanoplatelets can either move from the copper surface onto the carbon coating during the synthesis process, or form there from copper ions that have diffused from the copper surfaces.

Nanoplatelet precursor solutions were then deposited on copper tape surfaces to form nanoplatelets directly on the copper tape. Scanning electron microscopy images of the tape surfaces reveal the formation of Cu@HCl NPs with widths on the order of micrometers and thicknesses on the order of nanometers, as well as $\mathrm{Cu} @ \mathrm{HCl}-\mathrm{NH}_{2} \mathrm{NPs}$ that are wider than the $\mathrm{Cu} @ \mathrm{HCl}$ NPs (Figure 3). The increase in $\mathrm{Cu} @ \mathrm{HCl}-\mathrm{NH}_{2}$ NP widths can again be attributed to a role of diamine in the nanoplatelet crystallization process. XRD spectra reveal the presence of new peaks in $2 \theta$ ranges of $10^{\circ}$ to $40^{\circ}$ and $55^{\circ}$ to $60^{\circ}$ for $\mathrm{Cu} @ \mathrm{HCl} \mathrm{NPs}$ and $\mathrm{Cu} @ \mathrm{HCl}-\mathrm{NH}_{2} \mathrm{NPs}$, in addition to the peaks in the $2 \theta$ range of $40^{\circ}$ to $55^{\circ}$ that are from the $\mathrm{Cu}$ tape itself. The new peaks that resulted from nanoplatelet formation had some alignment with peaks in the XRD spectra of copper chloride, further suggesting that the nanoplatelets are composed of copper chloride crystals. However, SEM images of commercially obtained $\mathrm{Cu}$ (II) chloride powder revealed much larger and irregularly-shaped crystals (Figure S3), indicating that the nanoplatelets that have been formed on the copper surfaces do not reflect the typical morphology of copper chloride powders, and are instead more ordered in structure. It is important to note that the XRD peaks resulting from copper tape cannot be separated from the signal resulting from the nanoplatelets, as the nanoplatelets are formed directly on copper tape. FT-IR spectra of $\mathrm{Cu} \mathrm{HCl}$ NPs and Cu@HCl-NH 2 NPs reveal many spectral similarities to that of Cu tape, with the addition of multiple sharp peaks in $800 \mathrm{~cm}^{-1}$ to $1250 \mathrm{~cm}^{-1}$ range. Peaks at approximately $1580 \mathrm{~cm}^{-1}, 1263 \mathrm{~cm}^{-1}$, and $1116 \mathrm{~cm}^{-1}$ are observed for Cu tape, Cu@HCl 
NPs, and Cu@HCl-NH 2 NPs. Peaks at approximately $988 \mathrm{~cm}^{-1}, 921 \mathrm{~cm}^{-1}$, and $834 \mathrm{~cm}^{-1}$ are observed for Cu@HCl NPs and Cu@HCl-NH2 NPs. A peak at approximately 1060 $\mathrm{cm}^{-1}$ is observed for only the $\mathrm{Cu} @ \mathrm{HCl}-\mathrm{NH}_{2} \mathrm{NPs}$. These results suggest high similarity in composition between the $\mathrm{Cu} @ \mathrm{HCl}$ NPs, and $\mathrm{Cu} @ \mathrm{HCl}-\mathrm{NH}_{2}$ NPs. As with the XRD spectra, it is important to note that the FTIR signal resulting from copper tape cannot be separated from the signal resulting from the nanoplatelets, as the nanoplatelets are formed directly on copper tape. Despite these limitations, these results suggest that the nanoplatelets are composed of copper chloride, although it cannot be said with certainty whether they are $\mathrm{Cu}(\mathrm{I})$ chloride or $\mathrm{Cu}(\mathrm{II})$ chloride. The ability for nanoplatelets to be synthesized on other copper surfaces such as copper electrodes and copper granules was also confirmed with SEM (Figures S4, S5).

(A)

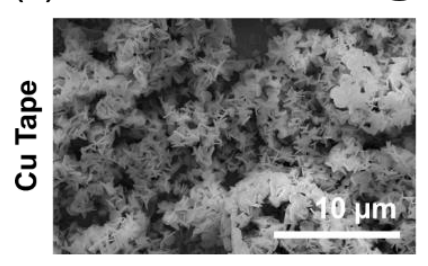

(B)

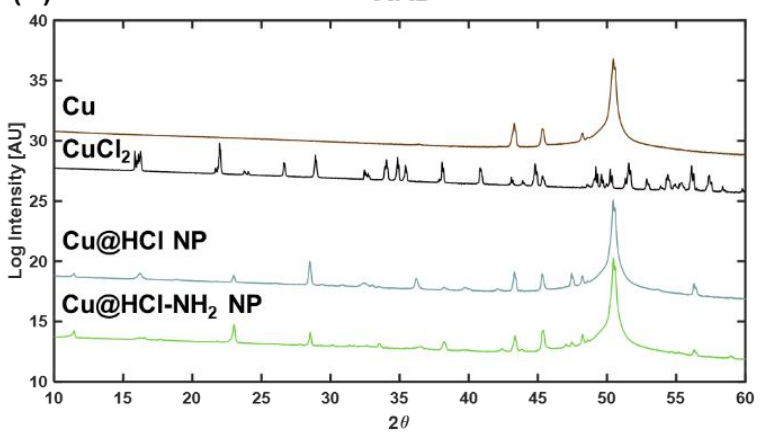

$\mathrm{Cu} \mathrm{HClNP}$

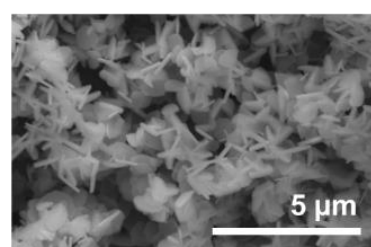

(C)

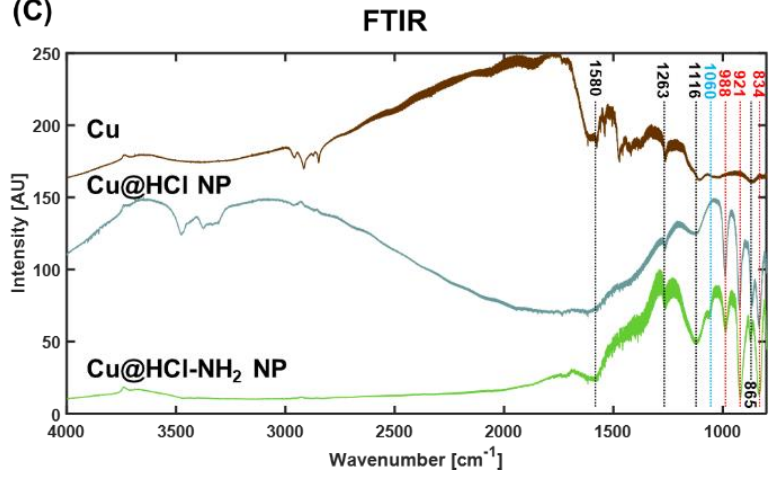

Figure 3. Characterization of copper chloride nanoplatelets formed on copper tape. (A) SEM images of nanoplatelets formed directly on copper tape: Cu@HCI NPs (left) and Cu@HCl-NH2 NPs (right). (B) XRD spectra of copper tape, copper (II) chloride powder, nanoplatelets formed directly on copper tape using the $\mathrm{HCl}$ solution, and nanoplatelets formed directly on copper tape using the $\mathrm{HCl}$ and diamine solution. (C) FTIR spectra of copper tape, $\mathrm{Cu} @ \mathrm{HCl}$ NPs, and $\mathrm{Cu} @ \mathrm{HCl}-\mathrm{NH}_{2}$ NPs formed directly on copper tape. Black lines mark peaks present in $\mathrm{Cu}, \mathrm{Cu} @ \mathrm{HCl} \mathrm{NPs}$, and $\mathrm{Cu} @ \mathrm{HCl}-\mathrm{NH}_{2} \mathrm{NPs}$; Red lines mark peaks present in both $\mathrm{Cu} @ \mathrm{HCl}$ NPs and $\mathrm{Cu} @ \mathrm{HCl}-\mathrm{NH}_{2}$ NPs but not in $\mathrm{Cu}$; Blue line marks peak present in only $\mathrm{Cu} @ \mathrm{HCl}-$ $\mathrm{NH}_{2} \mathrm{NPs}$. 


\section{Nanoplatelets inhibit $E$. coli and MDR E. coli bacterial growth}

To assess the antibacterial properties of the surfaces with copper nanoplatelets compared to those without, an experimental setup was created to enable continuous contact between bacterial suspensions with those surfaces. Cu tape, $\mathrm{Cu}$ tape on which $\mathrm{Cu} \mathrm{HCl}$ NPs were synthesized, and $\mathrm{Cu}$ tape on which $\mathrm{Cu} @ \mathrm{HCl}-\mathrm{NH}_{2}$ NPs were synthesized were adhered to the sides of 24-well plates (Figure 4B). Bacterial suspensions were then added to the wells, and optical density at $600 \mathrm{~nm}$ (OD600) values representing bacterial concentration were measured over time. The initial color of the surfaces with $\mathrm{Cu} @ \mathrm{HCl}-\mathrm{NH}_{2}$ NPs was observed to be bright green, while those with $\mathrm{Cu} @ \mathrm{HCl}$ NPs exhibited a lighter green color (Figure 4A). With increasing exposure time to the bacterial solutions, a change in color of both the nanoplatelet tape samples and the solution was observed (Figure 4A-B).

Changes in bacterial suspension color as a result of nanoplatelet treatment are apparent in both E. coli and MDR E. coli (Figure 4C and 4D). The exposure of the broth to nanoplatelet-covered surfaces without bacteria results in the appearance of a UVvisible absorbance peak at $600 \mathrm{~nm}$ (Figure S6). To account for the increase in absorbance at $600 \mathrm{~nm}$ due to copper tape with and without nanoplatelets in the absence of bacteria, the OD600 values for broth exposed to $\mathrm{Cu}$ tape and $\mathrm{Cu}$ tape with nanoplateletes were collected concurrently with, and subtracted from, the OD600 values for the bacteria-containing broth exposed to $\mathrm{Cu}$ tape and tape with nanoplatelet samples. In the presence of bacteria, the copper tape led to a smaller increase in OD600 values than when no tape was present at all, indicating a small amount of bacterial growth 
inhibition. However, the inhibition caused by the surfaces with Cu@HCl NPs and Cu@HCI-NH2 NPs represented a marked improvement over this. The OD600 values after $4 \mathrm{~h}$ of bacterial treatment were found to remain almost entirely unchanged for the Cu@HCl NPs and Cu@HCl-NH2 NPs, indicating almost complete inhibition of bacterial growth. This is also apparent in photographs of the wellplates after $4 \mathrm{~h}$ of treatment, with controls and bacterial suspensions exposed to copper tape having a greater opacity than suspensions exposed to copper tape with nanoplatelets (Figure S7). To ensure that the observed bacterial growth inhibition was not caused by the $\mathrm{HCl}$ or $\mathrm{HCl}-\mathrm{NH}_{2}$ solutions themselves, experiments were repeated with MDR E. coli exposure to liquid $\mathrm{HCl}$ solution or $\mathrm{HCl}-\mathrm{NH}_{2}$ solution at equivalent concentrations to those used in forming the nanoplatelets (Figure S8). The results reveal that the solutions themselves have little to no effect on OD600 values, confirming that the observed bacterial growth inhibition is a result of the presence of the nanoparticles on the copper surfaces. The mechanism of growth inhibition is not entirely clear. Considering the toxicity of copper ions, ${ }^{34,35}$ the inhibition likely results from the fact that the nanoplatelets increase the surface area from which copper ions can dissolve into solution and cause the growth inhibition. 
(A)
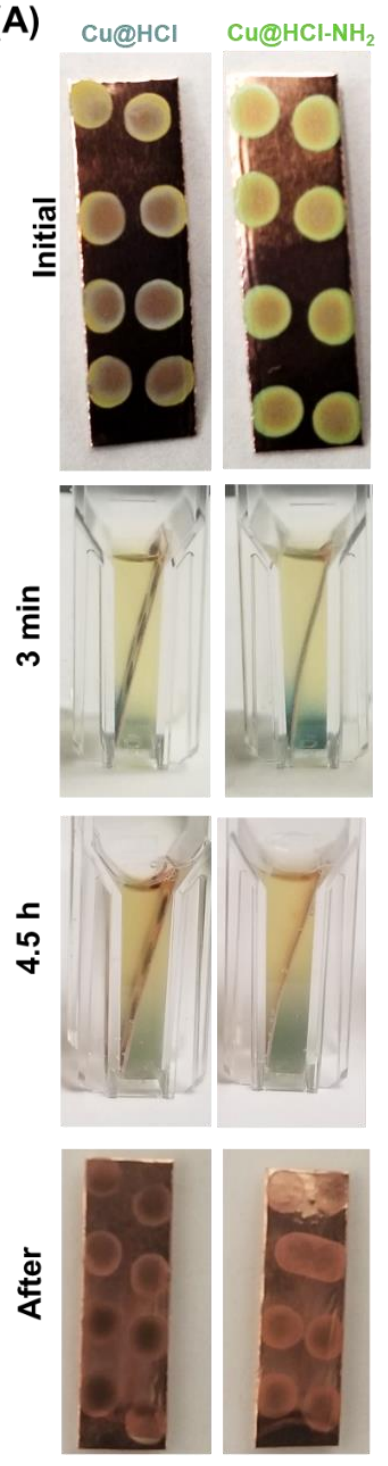

(B)

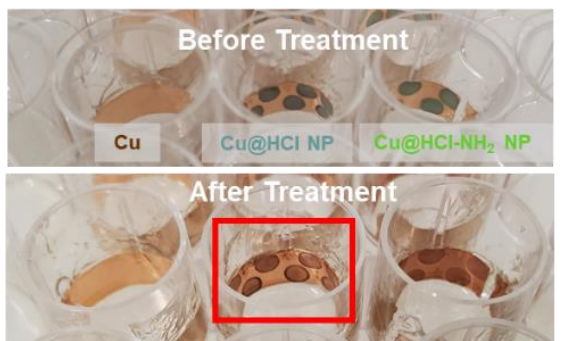

(C)
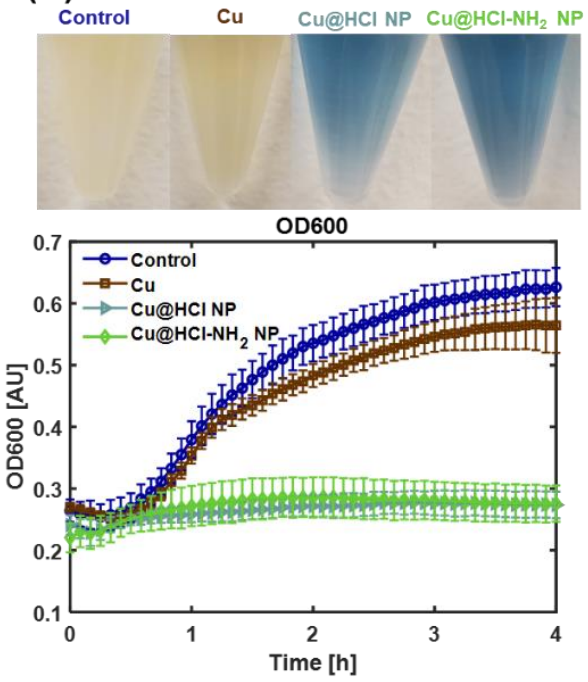

(D)
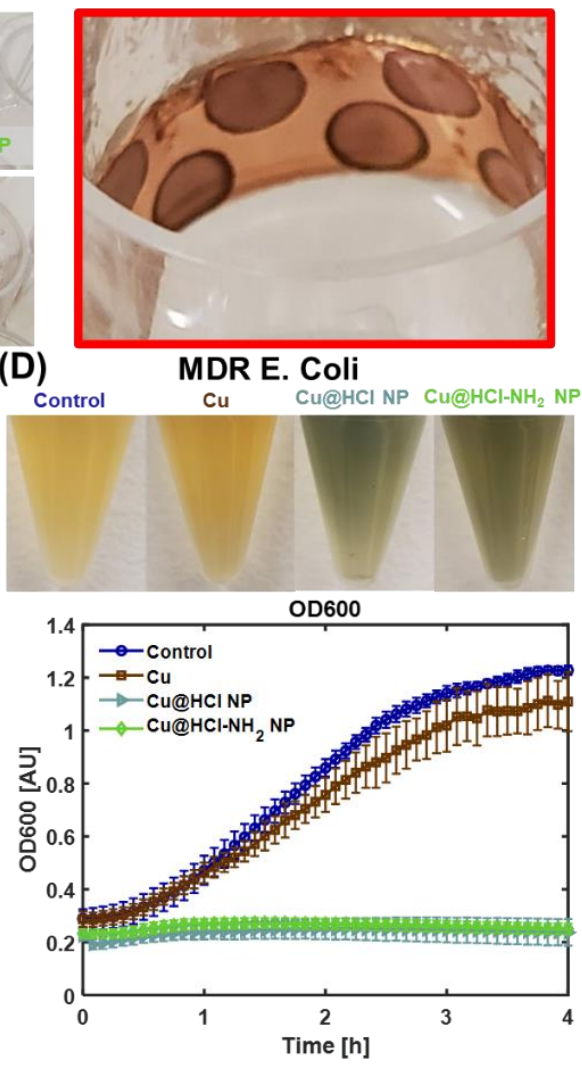

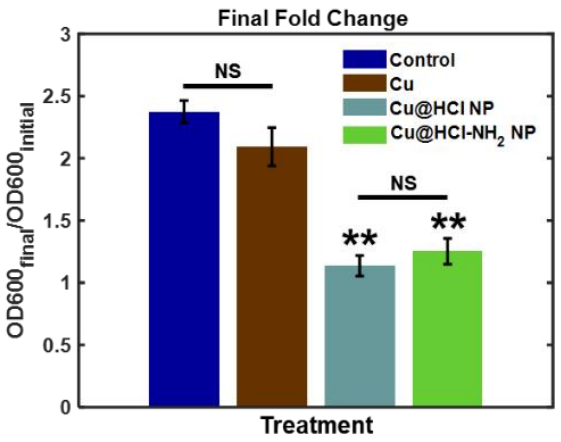

NS = not significant

** = statistical significance from control $(P<0.01)$

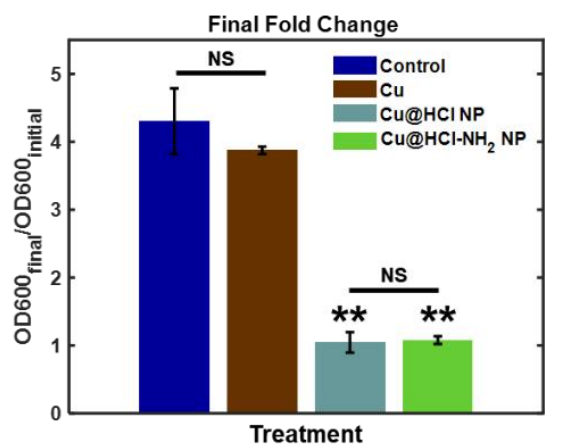

NS = not significant

** = statistical significance from control $(P<0.01)$

Figure 4. Inhibition of bacterial growth by nanoplatelets. (A) Nanoplatelet copper tape samples before and after exposure to bacteria. A visible color change occurs as a result of nanoplatelet dissolution into the bacterial broth. (B) Samples adhered to wells of 24-well plates. Top panel shows samples before exposure to bacteria, while bottom panel shows samples after exposure to bacteria. (C) Growth inhibition of E. coli in the presence of nanoplatelets. Nanoplatelets lead to almost complete inhibition of bacterial growth. Values represent averages and error bars represent standard deviations $(n=8$ for control, $n=4$ for treatment groups). ${ }^{* *}$ Denotes statistical significance from control, with $\mathrm{P}<0.01$. NS=not significant. Control samples are untreated bacterial solutions. (D) Growth inhibition of MDR E. coli in the presence of nanoplatelets. Nanoplatelets lead to almost complete inhibition of bacterial growth. Values represent averages and error bars represent standard deviations ( $\mathrm{n}=8$ for control, $\mathrm{n}=4$ for treatment groups). ${ }^{* *}$ Denotes statistical significance from control, with $\mathrm{P}<0.01$. NS=not significant. Control samples are untreated bacterial solutions. 


\section{Scanning electron microscopy reveals bacterial damage as a result of nanoplatelet treatments.}

Scanning electron microscopy images were taken of control MDR E. coli samples, as well as those treated with $\mathrm{Cu}, \mathrm{Cu} @ \mathrm{HCl}$ NPs, and $\mathrm{Cu} @ \mathrm{HCl}-\mathrm{NH}_{2}$ NPs for 4 h (Figure 5A). Control samples and Cu-treated samples retain a regular rod-like bacterial morphology, while samples exposed to nanoplatelet-covered copper surfaces have altered morphologies. In particular, exposure to those surfaces appears to lead to a wilting and flattening of bacterial samples. This is likely a result of an osmotic imbalance between the concentration of copper ions in the broth and in the bacterial cells. As copper ions are released from the dissolution of nanoplatelets into the bacterial suspension, a high concentration of copper ions would accumulate outside the bacterial cells and lead to hypertonic conditions. In response, the bacterial cells release water in an attempt to regain an equilibrium copper concentration between the bacteria and its environment, leading to the shriveled appearance in cells exposed to platelet-covered surfaces.

Scanning electron microscopy images taken of the tape substrates with which MDR E. coli samples were treated ( $\mathrm{Cu}, \mathrm{Cu} @ \mathrm{HCl} \mathrm{NPs}$, and $\mathrm{Cu} @ \mathrm{HCl}-\mathrm{NH}_{2}$ NPs) demonstrate a low adhesion between the bacterial cells and the copper substrates (Figure 5B). Furthermore, bacteria on the Cu substrate samples appear to retain their normal rod-like morphology, while those on the nanoplatelet surfaces have a shriveled appearance, further confirming the negative effects of the presence of nanoplatelets on bacterial cell morphology. 
(A)
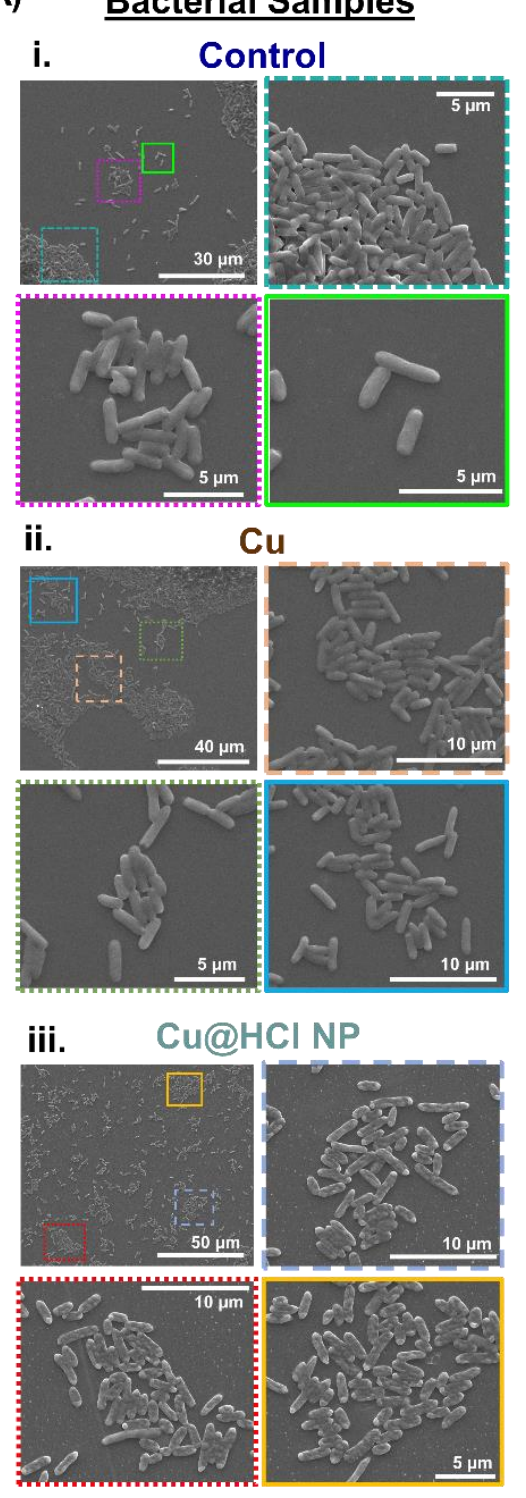

(B)
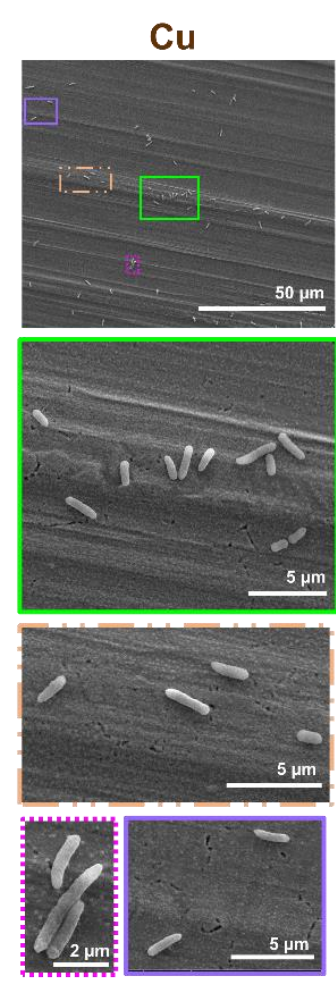

\section{Substrate Samples}
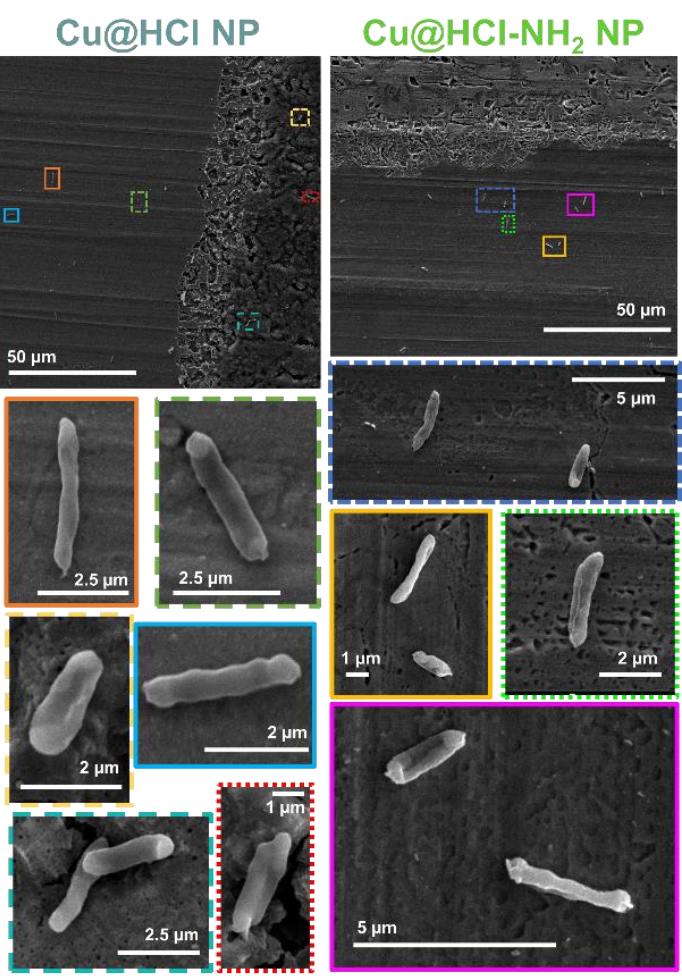

iv. $\mathrm{Cu} @ \mathrm{HCl}-\mathrm{NH}_{2} \mathrm{NP}$
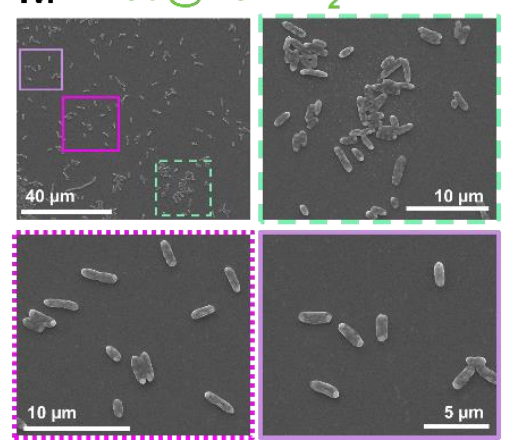

Figure 5. Scanning Electron Microscopy images of MDR E. coli treated with nanoplatelets. (A) Bacteria samples collected after $4 \mathrm{~h}$ of treatment. Insets depict higher magnification images of boxed regions. Untreated samples (controls) or samples treated with Cu tape alone exhibit regular bacterial morphologies (i-ii). Samples treated with $\mathrm{Cu} @ \mathrm{HCl}$ NPs or $\mathrm{Cu} @ \mathrm{HCl}-\mathrm{NH}_{2}$ NPs exhibit signs of bacterial damage, including a flattened and shriveled appearance (iii-iv). (B) Bacteria on copper substrates after treatment. Insets depict higher magnification images of boxed regions. Bacteria treated with copper alone exhibit relatively normal morphologies, and exhibit some adhesion to the copper surface. Bacteria treated with nanoplatelets have minimal adhesion to the surface, and exhibit signs of damage. 


\section{Exposure to nanoplatelet-covered copper surfaces reduced bacterial viability and} induced DNA damage.

Multiple studies were conducted to determine the mechanism by which the presence of nanoplatelets inhibit bacterial growth. Although OD600 measurements can provide information on the concentration of bacteria, they do not provide a direct measure of cell viability. To assess the viability of treated cells, live-dead staining of MDR E. coli was conducted using a commercial green stain for live cell indicator (live cell indicator) and propidium iodide (dead cell indicator), where a lower ratio of green to red fluorescence would indicate lower viability (Figure 6A). These studies demonstrated that the presence of nanoplatelet-covered copper surfaces not only inhibit bacterial cell division, but also reduced bacterial cell viability within only $4 \mathrm{~h}$ of exposure. This result is consistent with copper ion toxicity observed by others. ${ }^{34}$

Since cell division appeared to be affected by the presence of nanoplateletcovered copper surfaces, terminal deoxynucleotidyl transferase dUTP nick end labeling (TUNEL) assays were conducted to identify DNA damage in the bacterial samples (Figure 6B). In TUNEL assays, fragmented DNA is labelled with a fluorescent dye, and the presence of greater DNA fragmentation leads to a greater fluorescent intensity. $\mathrm{Cu}$ alone was found to lead to some DNA fragmentation, as can be expected from the antibacterial properties of Cu. However, the presence of $\mathrm{Cu} @ \mathrm{HCl}$ NPs and $\mathrm{Cu} @ \mathrm{HCl}-\mathrm{NH}_{2}$ NPs led to greater DNA fragmentation than the Cu treatment alone, confirming that the nanoplatelets provide a mechanism leading to a more potent antibacterial function. To further confirm this, gel electrophoresis was conducted on genomic DNA extracted from bacterial control samples, as well as bacterial samples treated with $\mathrm{Cu}, \mathrm{Cu} @ \mathrm{HCl} \mathrm{NPs}$, 
and $\mathrm{Cu} @ \mathrm{HCl}-\mathrm{NH}_{2} \mathrm{NPs}$ (Figure 6C). Exposure to nanoplatelet-covered surfaces reduced DNA band intensity for both E. coli and MDR E. coli, while untreated control samples and samples treated with Cu surfaces alone exhibited high band intensities, further confirming the role of nanoplatelets in preventing bacterial cell division by inducing DNA damage. To determine whether the nanoplatelets generated reactive oxygen species (ROS) that led to the DNA damage, ROS generation assays were conducted using $C M-\mathrm{H}_{2} \mathrm{DCFDA}$, a fluorescent ROS indicator that has high retention in cells, enabling long-term studies. CM- $\mathrm{H}_{2}$ DCFDA was loaded into MDR E. coli samples, and fluorescence intensity of the bacterial samples was monitored every $5 \min$ for $4 \mathrm{~h}$, with a greater fluorescence intensity corresponding to a higher presence of ROS. Although $\mathrm{Cu}$ alone was found to lead to some ROS generation near the beginning of the treatment, the presence of nanoplatelets on the copper surface was found to lead to lower fluorescence intensity than the control (Figure S9). This indicates that the nanoplatelets may in fact be acting as ROS scavengers rather than inducing ROS generation. To ensure that this observation was not a result of $\mathrm{CM}-\mathrm{H}_{2}$ DCFDA photobleaching with time, the experiment was repeated with bacterial samples protected from light during the experiment, and measurements collected only after $4 \mathrm{~h}$ of treatment (Figure S10). This further confirmed that ROS generation is not the mechanism by which nanoplatelet-induced DNA fragmentation occurred. Our results are consistent with those of Park et al., who found that copper ions do not increase hydroxyl radical production and may even reduce superoxide levels ${ }^{35}$. 
(A)

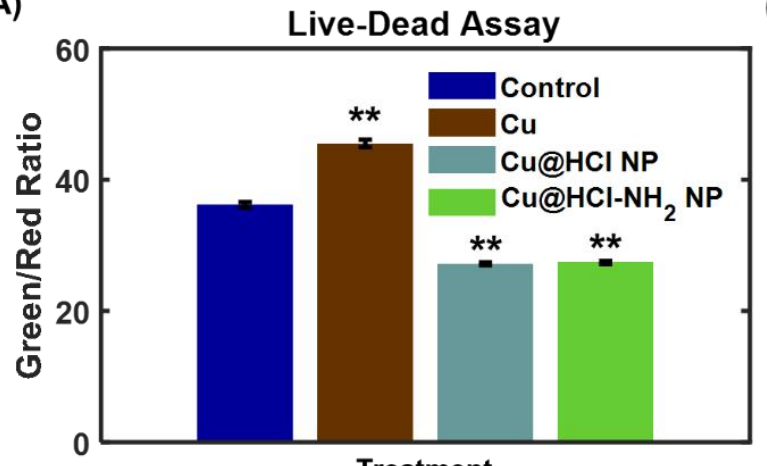

(C)

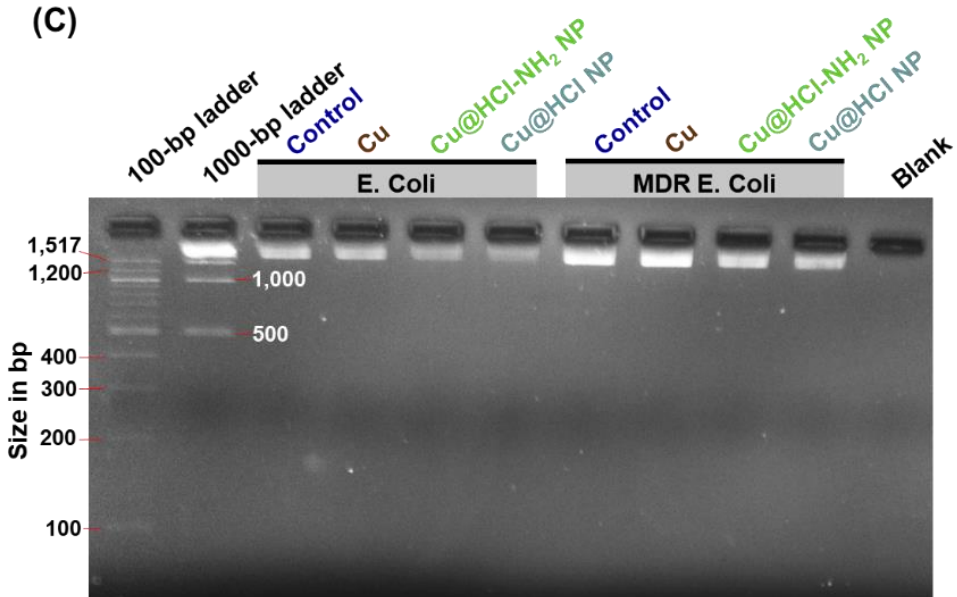

(B)

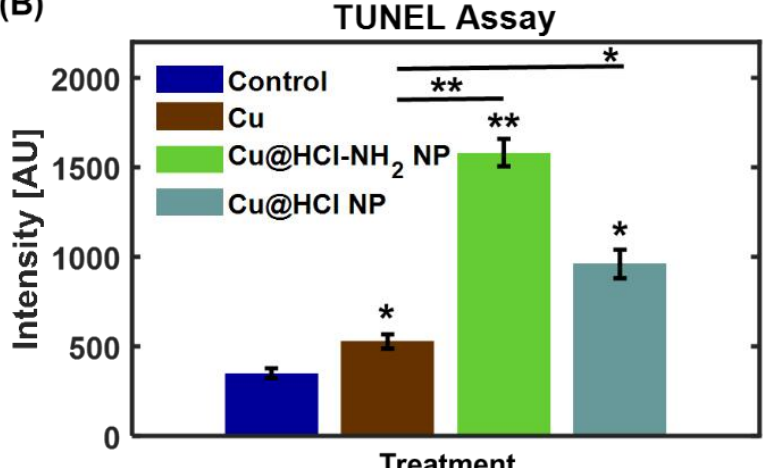

(D) SDS-PAGE

Figure 6. Exploration of mechanisms behind bacterial growth inhibition by nanoplatelets. (A) Live-Dead assay conducted on MDR E. coli treated with samples for $4 \mathrm{~h}$. A higher Green/Red ratio indicates greater cell viability. A reduction in cell viability is caused by the nanoplatelet treatments. Values represent averages and error bars represent standard deviations across three technical replicates. ${ }^{* *}$ indicates statistical significance with $P<0.01$. (B) TUNEL assay conducted on MDR E. coli treated with samples for $4 \mathrm{~h}$. A higher intensity indicates a greater level of DNA damage. Nanoplatelets induce greater DNA damage than $\mathrm{Cu}$ alone. Values represent averages and error bars represent standard deviations across three technical replicates. Asterisks over individual bars indicate statistical significance with respect to the control. ** indicates statistical significance with $\mathrm{P}<0.01$, ${ }^{*}$ indicates statistical significance with $\mathrm{P}<0.05$. (C) Gel electrophoresis results for genomic DNA extracted from E. coli and MDR E. coli treated with samples for 4 h. Reductions in band intensities for Cu@HCl NP-treated and Cu@HCl-NH $2 ~ N P$-treated samples confirm DNA damage induced by the nanoplatelets. These differences are apparent in both $E$. coli and MDR $E$. coli. (D) SDS-PAGE results for proteins extracted from E. coli and MDR E. coli treated with samples for 4 h. Nanoplatelets lead to reductions in band intensities, and in some cases complete removal of some protein bands, indicating that they have changes in protein expression. These changes are apparent in both $E$. coli than in MDR E. coli. 
Exposure to nanoplatelet-covered copper surfaces led to changes in bacterial protein expression.

In addition to evaluating DNA damage caused by the presence of nanoplatelets, further studies were conducted to evaluate the effects of nanoplatelet-covered copper surfaces on bacterial protein expression. Water-soluble proteins were extracted from untreated control samples, as well as bacteria exposed to copper surfaces, Cu@HCI NPs, and $\mathrm{Cu} @ \mathrm{HCl}-\mathrm{NH}_{2}$ NPs. SDS PAGE was conducted on these protein samples (Figure 6D), and demonstrates a clear difference in protein expression for nanoplatelet-treated bacteria compared to Cu-treated or untreated bacteria. These changes in protein expression are apparent for both E. coli and MDR E. coli. Furthermore, exposure to copper surfaces without nanoplatelets appeared to lead to little change in protein expression in either type of bacteria.

To examine this in greater detail, proteomic analysis was carried out to identify individual proteins present in the protein population extracted from the bacteria. Heatmaps were created using the $-10 \log \mathrm{P}$ values for all detected proteins for $E$. coli and MDR E. coli, where a higher -10logP value corresponds to a greater confidence in the identification of the proteins. In this work, we have divided -10logP values into 3 ranges: values greater than 75 are considered identification of the proteins with high confidence, values between 45 and 75 are considered identification of the proteins with acceptable confidence, and values below 45 are considered proteins that cannot be confidently identified in the samples. A list of all protein IDs and their corresponding protein Accession IDs and descriptions are provided in Table S1 and Table S2. 
Proteomic Analysis of MDR E. coli. There were fewer identified proteins in MDR E. coli samples exposed to copper surfaces without nanoplatelets (450 proteins), Cu@HClcovered copper surfaces (130 proteins), and Cu@HCl-NH2-covered copper surfaces (182 proteins) than in control samples that were not exposed to either surfaces (577 proteins). This confirms SDS PAGE observations which illustrated that exposure to nanoplateletcovered Cu surfaces had a major impact on protein expression.

A heatmap of identified proteins in the MDR E. coli samples is provided in Figure 7A. Three proteins related to cell division were identified in the control sample: 89 (P0A9A6|FTSZ_ECOLI, Cell division protein FtsZ), 630 (P0AF36|ZAPB_ECOLI, Cell division protein ZapB), and 734 (P45955|CPOB_ECOLI, Cell division coordinator CpoB). Protein 89 was identified with lower $-10 \log \mathrm{P}$ values in bacterial samples treated with $\mathrm{Cu}$, Cu@HCl NPs, or Cu@HCl-NH2 NPs, and protein 734 could not be confidently identified in these samples. A down-regulation of cell division proteins as a result of treatment can be directly related to the lack of cell division observed during the OD600 measurements.

Additionally, protein 78 (Q59385|COPA_ECOLI, Copper-exporting P-type ATPase) was identified in MDR E. coli treated with either $\mathrm{Cu}$ or nanoplatelets, but not in the control sample. Protein 458 (P36649|CUEO_ECOLI, blue copper oxidase), a protein believed to be involved in the detoxification of copper, was also identified in Cu-treated samples, but not in the control or the nanoplatelet-treated samples. Thus, the DNA damage caused by exposure to nanoplatelet-coated copper surfaces may have prevented the eventual synthesis of proteins that would provide the MDR E. coli with copper tolerance. In contrast, exposure to uncoated $\mathrm{Cu}$ surfaces may have led to the synthesis of proteins that would increase the copper tolerance of MDR E. coli. 
We further examined proteins related to DNA. Protein 58 (POAES4|GYRA_ECOLI, DNA gyrase subunit A), which is known to be involved in ATP-dependent breakage, passage and rejoining of double-stranded DNA, and therefore plays a role in its transcription, repair, and replication, is present in the control sample and Cu-treated sample, but not in the nanoplatelet-treated samples. Protein 90 (P00582|DPO1_ECOLI, DNA polymerase I) is also present in the control samples and samples exposed to uncoated copper surfaces, but not in those exposed to nanoplatelet-coated copper surfaces. This protein exhibits polymerase and exonuclease behaviors. Protein 114 (P0AES6|GYRB_ECOLI, DNA gyrase subunit B), which relaxes negatively supercoiled DNA, is identified with less confidence in the sample exposed to Cu surfaces than the control samples, and is not confidently identified in the samples exposed to nanoplateletcovered Cu surfaces. Proteins 410 (P06612|TOP1_ECOLI, DNA topoisomerase 1) and 1215 (P12295|UNG_ECOLI, Uracil-DNA glycosylase) could not be confidently identified in any of the treated samples, despite being identified in the control sample. These proteins are responsible for ATP-independent breakage of single-stranded DNA and releasing uracil residues respectively. Finally, protein 529 (POABE2|BOLA_ECOLI, DNAbinding transcriptional regulator BolA), which is known to have an impact on cell morphology, cell growth, and cell division, is identified in the control and Cu-exposed samples, but not confidently identified in the samples exposed to nanoplatelet-coated surfaces. Altogether, these results confirm that the exposure to nanoplatelet-covered surfaces had an impact on MDR E. coli cell division, response to copper, and DNA replication (Table 1). 
To develop an understanding of each sample's protein expression relative to the control sample, the ratio of each protein's ion counts to the total ion counts for each sample were calculated. This relative expression ratio was then divided by the relative expression ratio of the same proteins in the control sample. This enabled a comparison between the relative abundance of different proteins in the treated samples compared to the untreated control. Hierarchical clustering of these protein ratios identified similarities between samples exposed to nanoplatelet-covered surfaces compared to the samples exposed to copper surfaces without nanoplatelets (Figure 7B). In addition, the presence of nanoplatelets generally led to decreased expression of many proteins, while the absence of nanoplatelets on copper surfaces led to increased expression of some proteins critical to survival. For example, Cu-treated samples had an increased relative expression (compared to the control) of POABT2|DPS_ECOLI, which is responsible for protecting the bacterial cells from copper ion toxicity.

Table 1. Proteins of interest in MDR E. coli samples.

\begin{tabular}{|c|c|c|c|}
\hline $\begin{array}{l}\text { Protein } \\
\text { ID }\end{array}$ & Accession ID & Description & Observation \\
\hline 734 & P45955|CPOB_ECOLI & $\begin{array}{l}\text { Cell division } \\
\text { coordinator } \mathrm{CpoB}\end{array}$ & $\begin{array}{l}\text { Not identified in treated } \\
\text { samples }\end{array}$ \\
\hline 78 & Q59385|COPA_ECOLI & $\begin{array}{l}\text { Copper-exporting } \\
\text { P-type ATPase }\end{array}$ & $\begin{array}{l}\text { Identified in treated } \\
\text { samples but not in control }\end{array}$ \\
\hline 458 & P36649|CUEO_ECOLI & $\begin{array}{l}\text { Blue copper } \\
\text { oxidase }\end{array}$ & $\begin{array}{l}\text { Identified in Cu-treated } \\
\text { samples but not control or } \\
\text { nanoplatelet-treated } \\
\text { samples }\end{array}$ \\
\hline 410 & P06612|TOP1_ECOLI & $\begin{array}{l}\text { DNA } \\
\text { topoisomerase } 1\end{array}$ & \multirow[t]{2}{*}{$\begin{array}{l}\text { Not identified in treated } \\
\text { samples }\end{array}$} \\
\hline 1215 & P12295|UNG_ECOLI & $\begin{array}{l}\text { Uracil-DNA } \\
\text { glycosylase }\end{array}$ & \\
\hline 58 & P0AES4|GYRA_ECOLI & $\begin{array}{l}\text { DNA gyrase } \\
\text { subunit A }\end{array}$ & \multirow{2}{*}{$\begin{array}{l}\text { Not identified in } \\
\text { nanoplatelet-treated } \\
\text { samples }\end{array}$} \\
\hline 90 & P00582|DPO1_ECOLI & DNA polymerase I & \\
\hline
\end{tabular}




\begin{tabular}{|l|l|l|l|}
\hline 114 & POAES6|GYRB_ECOLI & $\begin{array}{l}\text { DNA gyrase } \\
\text { subunit B }\end{array}$ & \\
\hline
\end{tabular}

(A)

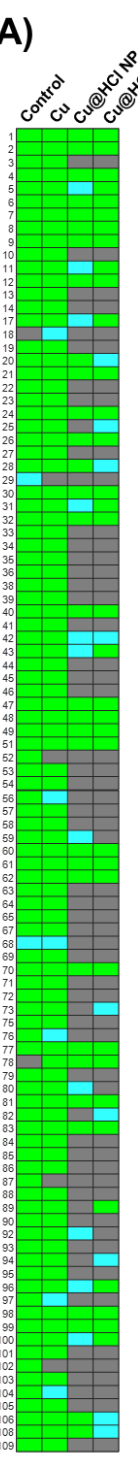

MDR E. Coli Protein Expression

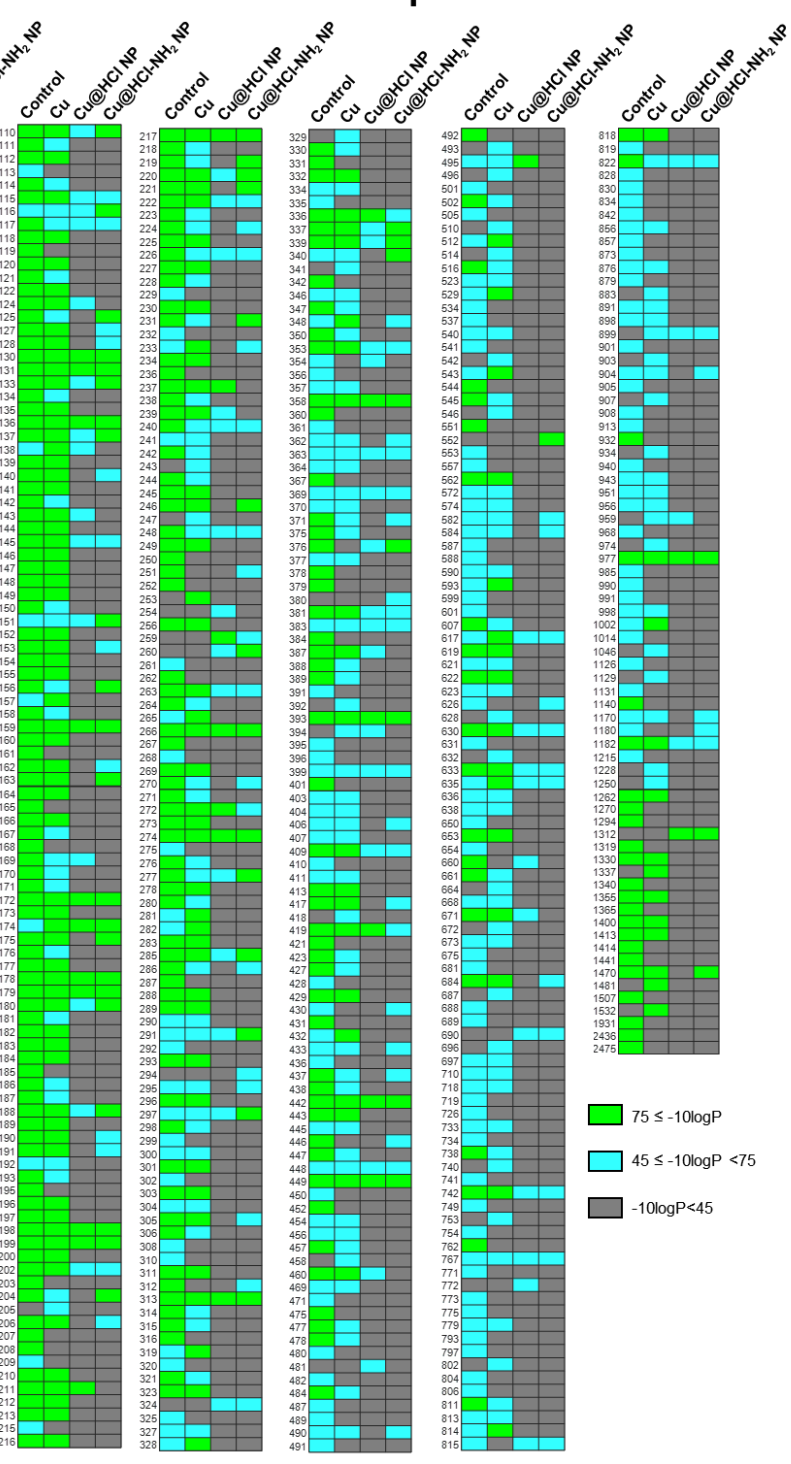

s(B)

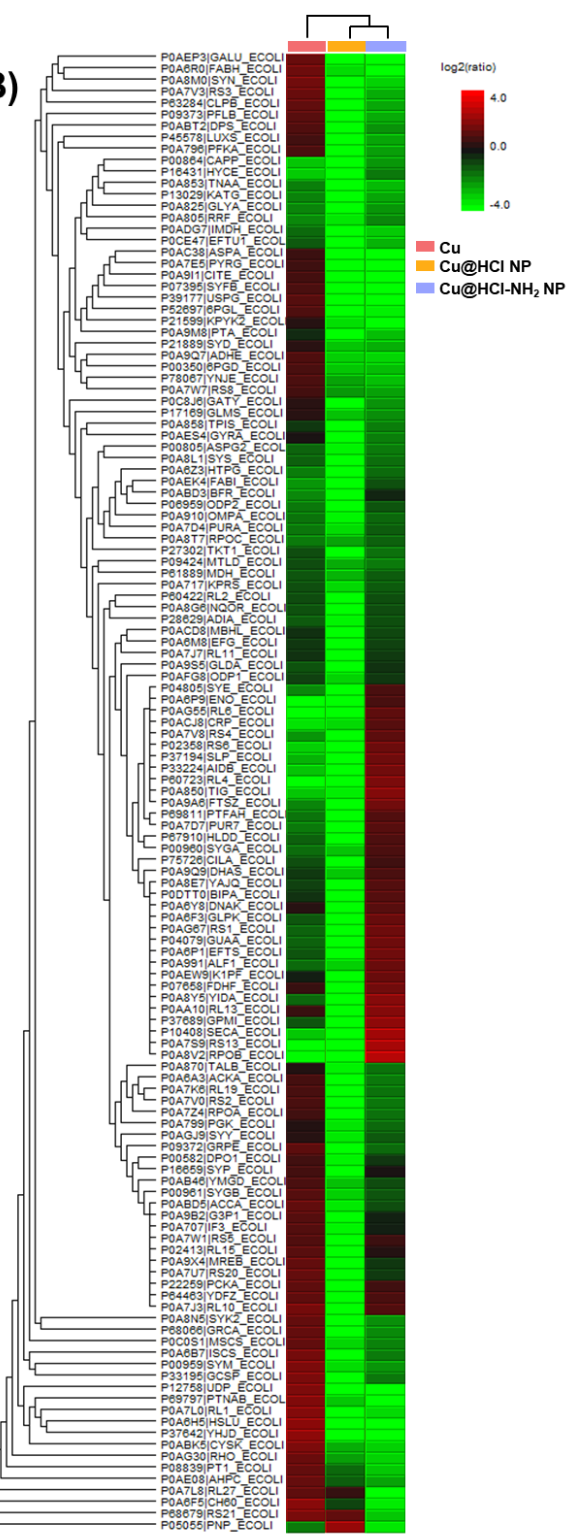

Figure 7. Proteomics analysis of MDR E. coli. (A) Heat maps classifying the -10logP values of each protein in each sample. Data represent a compilation of three technical replicates taken from each sample. (B) Hierarchical clustering of ratios between protein relative expression in each sample and protein relative expression in the control sample. Data represent the most data-rich technical replicate of three technical replicates for each sample. 
Proteomic Analysis of E. coli. As for MDR E. coli, there are fewer proteins in the E. coli samples treated with Cu (377 proteins), Cu@HCl NPs (178 proteins), and Cu@HCl-NH2 NPs (110 proteins) compared to the untreated control (611 proteins). This further confirms the E. coli SDS PAGE observations which illustrated that the presence of nanoplatelet had a major impact on protein expression.

A heatmap of identified proteins in the E. coli samples is provided in Figure $\mathbf{S 1 1}$ A. A number of proteins related to cell division were identified in the control sample. Protein 89 (POA9A6|FTSZ_ECOLI, Cell division protein FtsZ), which is responsible for forming a contractile ring structure ( $Z$ ring) at the future cell division site, was identified with high confidence in both the control and Cu-treated samples, but was identified with lower confidence in $\mathrm{Cu@HCl} \mathrm{NP-treated} \mathrm{copper} \mathrm{surfaces} \mathrm{and} \mathrm{could} \mathrm{not} \mathrm{be} \mathrm{confidently}$ identified in sample exposed to $\mathrm{Cu} @ \mathrm{HCl}-\mathrm{NH}_{2}$ NP-treated copper surfaces. Protein 900 (P0A734|MINE_ECOLI, Cell division topological specificity factor), which is responsible for ensuring the occurrence of cell division at the proper site, was identified in the control sample but not in the treated samples.

A number of proteins related to DNA were also altered in expression as a result of the exposure to copper surfaces. Protein 260 (POACF0|DBHA_ECOLI, DNA-binding protein HU-alpha), protein 265 (P0A800|RPOZ_ECOLI, DNA-directed RNA polymerase subunit omega), protein 272 (P0ACG1|STPA_ECOLI, DNA-binding protein StpA), protein 402 (P23909|MUTS_ECOLI, DNA mismatch repair protein MutS), protein 528 (P0ACBO|DNAB_ECOLI, Replicative DNA helicase), protein 837 (P21189|DPO2_ECOLI, DNA polymerase II), protein 1250 (POABS5|DNAG_ECOLI, DNA primase), and protein 1294 (P65556|YFCD_ECOLI, DNA primase) were all identified in the control sample but 
could not be confidently identified in any of the samples exposed to any of the copper surfaces (both coated and uncoated with nanoplatelets). Proteins 80 (P0A7Z4|RPOA_ECOLI, DNA-directed RNA polymerase subunit alpha), 85 (P0A9X4|MREB_ECOLI, DNA-directed RNA polymerase subunit omega), 86 (P04805|SYE_ECOLI, DNA-directed RNA polymerase subunit alpha), 90 (P00582|DPO1_ECOLI, DNA polymerase I), 114 (P0AES6|GYRB_ECOLI, DNA gyrase subunit B), and 529 (POABE2|BOLA_ECOLI, DNA-binding transcriptional regulator BolA) were all identified in the control and Cu-treated samples but not in the samples exposed to nanoplatelet-covered surfaces (Table 2).

Hierarchical clustering of $E$. coli protein ratios identified similarities between the samples exposed to nanoplatelet-covered surfaces compared to the samples exposed to bare copper surfaces (Figure S 11 B). As with MDR E. coli, exposure to nanoplatelets generally led to decreased expression of many proteins, while exposure to Cu surfaces without nanoplatelets led to increased expression of many proteins critical to survival. These findings further confirm the role of the presence of nanoplatelets in modulating protein expression.

Table 2. Proteins of interest in E. coli samples.

\begin{tabular}{|l|l|l|l|}
\hline $\begin{array}{l}\text { Protein } \\
\text { ID }\end{array}$ & Accession ID & Description & Observation \\
\hline 89 & P0A9A6|FTSZ_ECOLI & $\begin{array}{l}\text { Cell division protein } \\
\text { FtsZ }\end{array}$ & $\begin{array}{l}\text { Identified with high } \\
\text { confidence in control and } \\
\text { Cu-treated samples, lower } \\
\text { confidence in Cu@HCI } \\
\text { NP-treated samples, and } \\
\text { not identified in Cu@HCl- } \\
\mathrm{NH}_{2} \text { NP-treated samples }\end{array}$ \\
\hline 900 & P0A734|MINE_ECOLI & $\begin{array}{l}\text { Cell division } \\
\text { topological } \\
\text { specificity factor }\end{array}$ & \\
\hline
\end{tabular}




\begin{tabular}{|c|c|c|c|}
\hline 260 & POACFO|DBHA_ECOLI & $\begin{array}{l}\text { DNA-binding } \\
\text { protein HU-alpha }\end{array}$ & \multirow[t]{8}{*}{$\begin{array}{l}\text { Not identified in treated } \\
\text { samples }\end{array}$} \\
\hline 265 & P0A800|RPOZ_ECOLI & $\begin{array}{l}\text { DNA-directed RNA } \\
\text { polymerase subunit } \\
\text { omega }\end{array}$ & \\
\hline 272 & P0ACG1|STPA_ECOLI & $\begin{array}{l}\text { DNA-binding } \\
\text { protein StpA }\end{array}$ & \\
\hline 402 & P23909|MUTS_ECOLI & $\begin{array}{l}\text { DNA mismatch } \\
\text { repair protein MutS }\end{array}$ & \\
\hline 528 & POACBO|DNAB_ECOLI & $\begin{array}{l}\text { Replicative DNA } \\
\text { helicase }\end{array}$ & \\
\hline 837 & P21189|DPO2_ECOLI & DNA polymerase II & \\
\hline 1250 & POABS5|DNAG_ECOLI & DNA primase & \\
\hline 1294 & P65556|YFCD ECOLI & DNA primase & \\
\hline 80 & P0A7Z4|RPOA_ECOLI & $\begin{array}{l}\text { DNA-directed RNA } \\
\text { polymerase subunit } \\
\text { alpha }\end{array}$ & \multirow{6}{*}{$\begin{array}{l}\text { Not identified in } \\
\text { nanoplatelet-treated } \\
\text { samples }\end{array}$} \\
\hline 85 & P0A9X4|MREB_ECOLI & $\begin{array}{l}\text { DNA-directed RNA } \\
\text { polymerase subunit } \\
\text { omega }\end{array}$ & \\
\hline 86 & P04805|SYE_ECOLI & $\begin{array}{l}\text { DNA-directed RNA } \\
\text { polymerase subunit } \\
\text { alpha }\end{array}$ & \\
\hline 90 & P00582|DPO1_ECOLI & DNA polymerase & \\
\hline 114 & P0AES6|GYRB_ECOLI & $\begin{array}{l}\text { DNA gyrase } \\
\text { subunit B }\end{array}$ & \\
\hline 529 & POABE2|BOLA_ECOLI & $\begin{array}{l}\text { DNA-binding } \\
\text { transcriptional } \\
\text { regulator BolA }\end{array}$ & \\
\hline
\end{tabular}

\section{Nanostructures were also assembled directly on multiple other metal surfaces.}

To determine whether nanoplatelets could be assembled on other metal surfaces, the synthesis procedures were repeated by depositing the $\mathrm{HCl}$ solution or $\mathrm{HCl}$ and diamine solution onto pieces of tin, zinc, and cobalt and allowing the solution to dry. Scanning electron microscopy was then conducted on the samples (Figure S12, Figure S13). These images revealed the successful formation of nanostructures on these various metal surfaces. Although the structures differed in shape from one metal type to another, 
bioRxiv preprint doi: https://doi.org/10.1101/2021.09.28.462217; this version posted September 30, 2021. The copyright holder for this preprint (which was not certified by peer review) is the author/funder. All rights reserved. No reuse allowed without permission.

these results suggest a simple aqueous solution containing acid can be applied to metal surfaces to obtain textured nanoscale patterns and structures on the surfaces. 


\section{CONCLUSIONS}

We have developed a simple method to assemble metal-based nanostructures directly on metal surfaces without the need for prior synthesis of nanoparticles or inclusion of any metals within the precursor solution. We demonstrated that nanoplatelets could be formed on a variety of copper surfaces and explored their potential for use in antibacterial surfaces. We found that the copper surfaces with nanoplatelets had improved antibacterial activity compared to copper surfaces without nanoplatelets, likely as a result of an increased surface area from which copper ions can dissolve. Copper surfaces covered with nanoplatelets also induced structural and morphological changes in bacterial cells, and led to changes in protein and DNA expression. We further demonstrated that expression of specific proteins related to cell division, copper toxicity, and DNA division were altered as a result of the presence of nanoplatelets. Last, we demonstrated that other nanostructures could be formed by depositing our simple aqueous diluted $\mathrm{HCl}$ solution onto various metal surfaces. Overall, this study provides a simple method by which metal-based surfaces, especially those containing copper, can be modified to incorporate 2D nanostructures. 


\section{MATERIALS AND METHODS}

\section{Materials}

Copper granules, zinc strips, tin chips, and cobalt pieces were purchased from Chemistry Cabinet ${ }^{\ddagger}$. Other metal samples were obtained in the form of a copper anode sheet and zinc anode sheet. 300 to 400 mesh carbon coated copper TEM grids were purchased from Ted Pella $\ddagger$. Regular E. coli and multi-drug-resistant E. coli (ATCC BAA-201) were purchased from ATCC $\ddagger$. Loctite Clear Silicone Waterproof Sealant ${ }^{\ddagger}$ was used to adhere copper substrate samples to the wells of 24 -well plates. DNA extraction was conducted using a ZymoBIOMICS DNA Miniprep Kit (Zymo Research) $)^{\ddagger}$. Protein extraction was conducted using a Qproteome Bacterial Protein Prep Kit (Qiagen)‡, and protein digestions were conducted using an In-Solution Tryptic Digestion and Guanidination Kit (89895, ThermoFisher Scientific) ${ }^{\ddagger}$. CM- $\mathrm{H}_{2}$ DCFDA and the LIVE/DEAD BacLight Bacterial Viability Kit were purchased as kits from ThermoFisher Scientific ${ }^{\ddagger}$. The Cell Meter TUNEL apoptosis assay kit was purchased from AAT Bioquest ${ }^{\ddagger}$.

\section{Preparation of Nanoplatelet Precursor solution}

Solution for Cu@HCI NP: $50 \mu \mathrm{L}$ of $2 \mathrm{~N} \mathrm{HCl}$ was diluted with $1 \mathrm{~mL}$ of filtered water.

Solution for Cu@HCl-NH $2 \mathrm{NP}: 3.5 \mu \mathrm{L} 2$ 2'-(ethylenedioxy) bis(ethylamine) was diluted in $10 \mathrm{~mL}$ of filtered water. $50 \mu \mathrm{L}$ of $2 \mathrm{~N} \mathrm{HCl}$ was added to $1 \mathrm{~mL}$ of this solution.

\section{Synthesis of Nanoplatelets}

On TEM Grids: $2.5 \mu \mathrm{L}$ of precursor solution was drop-cast onto the uncoated side of carbon-coated copper TEM grids. Samples were allowed to dry for 2 min, after which 
excess liquid was removed using filter paper. The TEM grid was then allowed to dry until the imaging was conducted.

On Copper Tape and other metal substrates: $3.5 \mu \mathrm{L}$ of precursor solution was drop-cast onto the substrate and allowed to completely dry under atmospheric conditions. For bacterial experiments, eight $3.5 \mu \mathrm{L}$ drops of precursor solution were deposited on each 2-cm copper sample.

\section{Scanning Electron Microscopy of Nanoplatelet Samples}

Samples were imaged using a commercial environmental SEM at nominal acceleration voltages of $10 \mathrm{kV}$ to $20 \mathrm{kV}$. Samples were not coated prior to imaging.

\section{FT-IR and XRD}

FT-IR samples were prepared by adhering copper tape samples directly onto corner frosted FT-IR slides. FT-IR measurements were taken with a commercial FT-IR spectrometer. XRD was conducted on powder samples using a commercial XRD system. XRD spectra were collected for nanoplatelet samples directly on the Cu tape substrate.

\section{Bacterial Culture}

E. coli was cultured in Luria-Bertani (LB) broth at $37^{\circ} \mathrm{C}$ under aerobic conditions. MDR E. coli was cultured at $37{ }^{\circ} \mathrm{C}$ under aerobic conditions in Tryptic Soy Medium supplemented with $10 \mu \mathrm{g} / \mathrm{ml}$ Ceftazidime. 


\section{Bacterial optical density experiments}

Copper substrates or nanoplatelet samples were adhered to the wells of a 24-well plate using waterproof silicone glue. Two $2 \mathrm{~cm}$ sample strips were used for each well. The glue was allowed to completely dry before experiments were conducted. $2 \mathrm{~mL}$ of bacteria with an optical density of approximately 0.25 were added to each well of the 24 -well plates. OD600 values were measured kinetically at $37^{\circ} \mathrm{C}$ for $4 \mathrm{~h}$ in a plate reader.

\section{Bacterial optical density experiments using precursor solutions}

$2 \mathrm{~mL}$ of MDR E. coli bacteria with an optical density of approximately 0.25 were added to 12 wells of a 24 -well plate. $2 \mathrm{~mL}$ of bacterial broth were added to the remaining 12 wells of a 24-well plate. For treatment groups, $56 \mu \mathrm{L}$ of nanoplatelet precursor solution was added to each well. OD600 values were measured kinetically at $37^{\circ} \mathrm{C}$ for $4 \mathrm{~h}$ in a plate reader.

\section{Scanning Electron Microscopy of substrates used to treat bacteria}

$2 \mathrm{~mL}$ of MDR E. coli with an initial optical density of approximately 0.25 was exposed to two $2 \mathrm{~cm}$ long copper tape samples or nanoplatelet samples for $4 \mathrm{~h}$ at $37^{\circ} \mathrm{C}$ in an incubator-shaker. Following this, samples were fixed in a $2 \%$ paraformaldehyde, $2.5 \%$ glutaraldehyde solution for $10 \mathrm{~min}$, and sequentially dehydrated in solutions of $25 \%, 50$ $\%, 75 \%, 95 \%$, and $100 \%$ ethanol for 10 min each. The samples were then allowed to dry under atmospheric conditions. Prior to imaging, samples were coated with platinumpalladium. Samples were imaged on a commercial SEM with a $10 \mathrm{kV}$ nominal acceleration voltage. 


\section{Scanning Electron Microscopy of bacteria after exposure to substrates}

$2 \mathrm{~mL}$ of MDR E. coli with an initial optical density of approximately 0.25 was exposed to two $2 \mathrm{~cm}$ long copper tape samples or nanoplatelet samples for $4 \mathrm{~h}$ at $37^{\circ} \mathrm{C}$ in an incubator-shaker. Following this, the bacterial suspensions were centrifuged at $626 \mathrm{rad} / \mathrm{s}$ (5976 rpm), $39200 \mathrm{~m} / \mathrm{s}^{2}(4000 \times \mathrm{g})$ for $15 \mathrm{~min}$, and resuspended in $0.5 \mathrm{~mL} 2 \%$ volume fraction paraformaldehyde/water solution, $2.5 \%$ volume fraction glutaraldehyde/water solution for $10 \mathrm{~min}$. The suspensions were then centrifuged for $10 \mathrm{~min}$ and resuspended in $25 \%$ volume fraction ethanol/water solution for $10 \mathrm{~min}$. Suspensions were then sequentially centrifuged $\left(626 \mathrm{rad} / \mathrm{s}(5976 \mathrm{rpm}), 39200 \mathrm{~m} / \mathrm{s}^{2}(4000 \times \mathrm{g}), 5 \mathrm{~min}\right)$ and resuspended in $0.5 \mathrm{~mL}$ of $50 \%, 75 \%$, and $95 \%$ volume fraction ethanol/water solutions, with samples retained in each solution for 5 min prior to centrifugation. Finally, the samples were in $250 \mu \mathrm{L} 100 \%$ ethanol, and $50 \mu \mathrm{L}$ of each sample was deposited onto a glass coverslip and allowed to dry under atmospheric conditions. Prior to imaging, samples were coated with platinum-palladium. Samples were imaged on a commercial SEM with a $10 \mathrm{kV}$ nominal acceleration voltage.

\section{ROS Generation Assay}

$50 \mu \mathrm{g} \mathrm{CM}-\mathrm{H}_{2}$ DCFDA dye was dissolved in $8.65 \mu \mathrm{L}$ dimethyl sulfoxide [DMSO], and $8 \mu \mathrm{L}$ of this solution was added to $8 \mathrm{~mL}$ bacterial broth. $20 \mathrm{~mL}$ of bacteria was suspended at an OD600 value of 0.25 . The bacteria was centrifuged at $700 \mathrm{rad} / \mathrm{s}(6682 \mathrm{rpm}), 49000$ $\mathrm{m} / \mathrm{s}^{2}(5000 \times \mathrm{g})$ for $5 \mathrm{~min}$ and then resuspended in the bacterial medium containing the CM- $\mathrm{H}_{2}$ DCFDA dye. The bacteria was protected from light and incubated in a shakerincubator at $37{ }^{\circ} \mathrm{C}$ for $5 \mathrm{~min}$. The suspension was then centrifuged at $626 \mathrm{rad} / \mathrm{s}$ 
(5976 rpm), $39200 \mathrm{~m} / \mathrm{s}^{2}(4000 \times \mathrm{g})$ for $5 \mathrm{~min}$, and the bacteria was resuspended in $8 \mathrm{ml}$ fresh medium. The centrifugation process was repeated one more time, and the bacterial pellet was finally resuspended in $20 \mathrm{~mL}$ fresh medium. $1 \mathrm{~mL}$ of bacterial suspension was placed in each centrifuge tube, and the suspensions were treated with the copper tape or nanoplatelets, after which fluorescence measurements were collected in accordance with kit directions.

\section{Live-Dead Assay}

$2 \mathrm{~mL}$ of MDR E. coli with an initial optical density of approximately 0.25 was exposed to two $2 \mathrm{~cm}$ long copper tape samples or nanoplatelet samples for $4 \mathrm{~h}$ at $37^{\circ} \mathrm{C}$ in an incubator-shaker. Following this, $0.75 \mathrm{~mL}$ of each sample was collected and centrifuged to form a bacterial cell pellet. The pellet was then resuspended in $\mathrm{NaCl}$ solution with a volume fraction of $0.85 \%$, and three $100 \mu \mathrm{L}$ aliquots from each solution were added into the wells of a 96 -well plate. $100 \mu \mathrm{L}$ of live-dead solution (prepared according to manufacturer guidelines) was added to each well. Samples were incubated in the dark at room temperature for $15 \mathrm{~min}$, after which fluorescence spectra were collected

\section{TUNEL Assay}

$2 \mathrm{~mL}$ of MDR E. coli with an initial optical density of approximately 0.25 was exposed to two $2 \mathrm{~cm}$ long copper tape samples or nanoplatelet samples for $4 \mathrm{~h}$ at $37^{\circ} \mathrm{C}$ in an incubator-shaker. Following this, $0.75 \mathrm{~mL}$ of each sample was collected and centrifuged to form a bacterial cell pellet. Each pellet was then resuspended in $150 \mu \mathrm{L}$ TUNEL solution (12.5 $\mu \mathrm{L}$ tunnelyte diluted in $1.25 \mathrm{~mL}$ reaction buffer) and placed on an incubator-shaker 
at $37^{\circ} \mathrm{C}$ for $1 \mathrm{~h}$. Samples were then pelleted and resuspended in $300 \mu \mathrm{L}$ reaction buffer and three $100 \mu \mathrm{L}$ aliquots ( 3 technical replicates) of each sample were pipetted into the wells of a 96-well plate. Fluorescence spectra were collected for each well (excitation 550 $\mathrm{nm}$, emission range: $590 \mathrm{~nm}$ to $650 \mathrm{~nm}$, gain of 150), and the peak emission intensity was averaged across all technical replicates for each sample.

\section{DNA Extraction}

$2 \mathrm{~mL}$ of MDR E. coli with an initial optical density of approximately 0.25 was exposed to two $2 \mathrm{~cm}$ long copper tape samples or nanoplatelet samples for $4 \mathrm{~h}$ at $37^{\circ} \mathrm{C}$ in an incubator-shaker. DNA was extracted following the guidelines provided by the kit manufacturer. Samples were stored frozen at $-20^{\circ} \mathrm{C}$ until further use.

\section{DNA gel electrophoresis}

Agarose gels were prepared by adding $2 \mathrm{~g}$ agarose to $100 \mathrm{~mL}$ Tris-Borate-EDTA (TBE) buffer and heating the solution in a microwave. Ethidium bromide was added into the solution, and the gel was poured into the mold and allowed to cool. $50 \mathrm{ng}$ of each DNA sample was added to their respective wells, and the gel was run at $120 \mathrm{~V}$ for $75 \mathrm{~min}$.

\section{Protein Extraction}

$2 \mathrm{~mL}$ of MDR E. coli with an initial optical density of approximately 0.25 was exposed to two $2 \mathrm{~cm}$ long copper tape samples or nanoplatelet samples for $4 \mathrm{~h}$ at $37^{\circ} \mathrm{C}$ in an incubator-shaker. Water-soluble proteins were then extracted from bacteria following the guidelines in the obtained kit. Samples were stored frozen at $-80^{\circ} \mathrm{C}$ until further use. 


\section{SDS PAGE}

Protein concentration was determined and samples were diluted to a concentration of 1 $\mu \mathrm{g} / \mu \mathrm{L}$ and run on a $7.5 \%$ pre-cast gel at $115 \mathrm{~V}$ for $48 \mathrm{~min}$, after which they were stained and imaged on a gel imager.

\section{Statistical Analysis}

Statistical analysis was conducted with two-tailed Student's T-tests. Bonferroni corrections were used to determine adjusted $\mathrm{P}$ values in cases where multiple comparisons were conducted.

\section{Proteomics Analysis}

Protein concentration was determined using a Nanodrop ${ }^{\ddagger}$. Samples were diluted to a concentration of $1 \mu \mathrm{g} / \mu \mathrm{L}$ and a $10 \mu \mathrm{L}$ aliquot was digested following the kit instructions. Samples were stored at $-20^{\circ} \mathrm{C}$ and submitted to the UMBC Molecular Characterization and Analysis Complex for label-free proteomic analysis.

\section{ACKNOWLEDGEMENTS}

We gratefully acknowledge Dr. Priyanka Ray and Dr. Parikshit Moitra for their helpful comments and assistance with electrophoresis experiments, as well as Dr. Aaron Schwartz-Duval for his helpful comments. This project was partially funded through grants from the National Institutes of Health, Department of Defense, and University of Illinois. P. Fathi was supported by the National Physical Science Consortium and the National Institute of Standards \& Technology through a National Physical Science Consortium 
(NPSC) graduate fellowship and by the Nadine Barrie Smith Memorial Fellowship from the Beckman Institute. Research reported in this publication was supported by the National Institute of Biomedical Imaging and Bioengineering of the National Institutes of Health under Award Number T32EB019944. This work was carried out in part in the Frederick Seitz Materials Research Laboratory Central Research Facilities, University of Illinois.

$\ddagger$ Commercial entities, equipment or materials may be identified in this document to describe an experimental procedure or concept adequately. Such identification is not intended to imply recommendation or endorsement by the National Institute of Standards and Technology, nor is it intended to imply that the entities, materials or equipment are necessarily the best available for the purpose.

\section{REFERENCES}

1. Cobrado, L., Silva-Dias, A., Azevedo, M. M. \& Rodrigues, A. G. High-touch surfaces: microbial neighbours at hand. Eur. J. Clin. Microbiol. Infect. Dis. 36, 2053-2062 (2017).

2. Hasan, J., Crawford, R. J. \& Ivanova, E. P. Antibacterial surfaces: The quest for a new generation of biomaterials. Trends Biotechnol. 31, 295-304 (2013).

3. Ramos, A. P., Cruz, M. A. E., Tovani, C. B. \& Ciancaglini, P. Biomedical applications of nanotechnology. Biophys. Rev. 9, 79-89 (2017).

4. Murthy, S. K. Nanoparticles in modern medicine: state of the art and future challenges. Int. J. Nanomedicine 2, 129-41 (2007).

5. Fathi, P. et al. Bulk-state and single-particle imaging are central to understanding carbon dot photo-physics and elucidating the effects of precursor composition and reaction temperature. Carbon N. Y. 145, 572-585 (2019).

6. Fathi, P. \& Pan, D. Current trends in pyrrole and porphyrin-derived nanoscale materials for biomedical applications. Nanomedicine (Lond). 15, (2020).

7. Zahin, N. et al. Nanoparticles and its biomedical applications in health and diseases: special focus on drug delivery. Environ. Sci. Pollut. Res. 27, 1915119168 (2020).

8. Pearce, A. K., Wilks, T. R., Arno, M. C. \& Reilly, R. K. O. Synthesis and applications of anisotropic nanoparticles with precisely defined dimensions $\square$. 
Nat. Rev. Chem. (2020). doi:10.1038/s41570-020-00232-7

9. Zhao, Z. et al. Systemic tumour suppression via the preferential accumulation of erythrocyte-anchored chemokine-encapsulating nanoparticles in lung metastases. Nat. Biomed. Eng. (2020). doi:10.1038/s41551-020-00644-2

10. Parayath, N. N., Stephan, S. B., Koehne, A. L., Nelson, P. S. \& Stephan, M. T. nanocarriers for transient expression in circulating. Nat. Commun. doi:10.1038/s41467-020-19486-2

11. Liu, S. et al. Treatment of infarcted heart tissue via the capture and local delivery of circulating exosomes through antibody-conjugated magnetic nanoparticles. Nat. Biomed. Eng. 4, 1063-1075 (2020).

12. Benfenati, F. \& Lanzani, G. Clinical translation of nanoparticles for neural stimulation. Nat. Rev. Mater. 2-5 (2020). doi:10.1038/s41578-020-00267-8

13. Croissant, J. G., Butler, K. S., Zink, J. I. \& Brinker, C. J. Synthetic amorphous silica nanoparticles: toxicity, biomedical and environmental implications. Nat. Rev. Mater. 5, (2020).

14. Fathi, P. et al. Biodegradable Biliverdin Nanoparticles for Efficient Photoacoustic Imaging. ACS Nano 13, 7690-7704 (2019).

15. Agarwal, R. et al. Inhaled bacteriophage-loaded polymeric microparticles ameliorate acute lung infections. Nat. Biomed. Eng. 2, 841-849 (2018).

16. Hussain, S. et al. Antibiotic-loaded nanoparticles targeted to the site of infection enhance antibacterial efficacy. Nat. Biomed. Eng. 2, 95-103 (2018).

17. Lee, J. et al. Development of Multimodal Antibacterial Surfaces Using Porous Amine-Reactive Films Incorporating Lubricant and Silver Nanoparticles. ACS Appl. Mater. Interfaces (2019). doi:10.1021/acsami.8b20092

18. Jalil, S. A. et al. Creating superhydrophobic and antibacterial surfaces on gold by femtosecond laser pulses. Appl. Surf. Sci. 506, 0-6 (2020).

19. Wang, Y. et al. Smart, Photothermally Activated, Antibacterial Surfaces with Thermally Triggered Bacteria-Releasing Properties. ACS Appl. Mater. Interfaces 12, 21283-21291 (2020).

20. Bezza, F. A., Tichapondwa, S. M. \& Chirwa, E. M. N. Fabrication of monodispersed copper oxide nanoparticles with potential application as antimicrobial agents. Sci. Rep. 10, 1-18 (2020).

21. Alafeef, M., Dighe, K. \& Pan, D. Label-Free Pathogen Detection Based on Yttrium-Doped Carbon Nanoparticles up to Single-Cell Resolution. ACS Appl. Mater. Interfaces 11, 42943-42955 (2019).

22. Alafeef, M., Moitra, P. \& Pan, D. Nano-enabled sensing approaches for pathogenic bacterial detection. Biosens. Bioelectron. 165, 112276 (2020).

23. Rosenbaum, J. et al. Antibacterial properties of nanostructured $\mathrm{Cu}-\mathrm{TiO} 2$ surfaces for dental implants. Biomater. Sci. 5, 455-462 (2017).

24. Liu, R. et al. In vitro and in vivo studies of anti-bacterial copper-bearing titanium alloy for dental application. Dent. Mater. 34, 1112-1126 (2018).

25. Mittapally, S., Taranum, R. \& Parveen, S. Metal ions as antibacterial agents. J. Drug Deliv. Ther. 8, 411-419 (2018).

26. Singha, P., Locklin, J., Handa, H. \& Author, A. B. A Review of the Recent Advances in Antimicrobial Coatings for Urinary Catheters Graphical Abstract HHS Public Access Author manuscript. Acta Biomater 50, 20-40 (2017). 
27. Liu, R. et al. Antibacterial effect of copper-bearing titanium alloy (Ti-Cu) against Streptococcus mutans and Porphyromonas gingivalis. Sci. Rep. 6, 1-10 (2016).

28. Astasov-Frauenhoffer, M. et al. Antimicrobial efficacy of copper-doped titanium surfaces for dental implants. J. Mater. Sci. Mater. Med. 30, 1-9 (2019).

29. Ching, C. \& Zaman, M. H. Development and selection of low-level multi-drug resistance over an extended range of sub-inhibitory ciprofloxacin concentrations in Escherichia coli. Sci. Rep. 10, 1-9 (2020).

30. Mukherjee, S. et al. Antimicrobial Drug-Resistant Shiga Toxin-Producing. 23, 2015-2017 (2017).

31. Ghanem, B. \& Haddadin, R. N. Multiple drug resistance and biocide resistance in Escherichia coli environmental isolates from hospital and household settings.

Antimicrob. Resist. Infect. Control 7, 1-7 (2018).

32. Miryala, S. K. \& Ramaiah, S. Exploring the multi-drug resistance in Escherichia coli O157:H7 by gene interaction network: A systems biology approach. Genomics 111, 958-965 (2019).

33. Tadesse, D. A. et al. Antimicrobial drug resistance in Escherichia coli from humans and food animals, United States, 1950-2002. Emerg. Infect. Dis. 18, 741749 (2012).

34. Giachino, A. \& Waldron, K. J. Copper tolerance in bacteria requires the activation of multiple accessory pathways. Mol. Microbiol. 114, 377-390 (2020).

35. Park, H. J., Nguyen, T. T. M., Yoon, J. \& Lee, C. Role of reactive oxygen species in Escherichia coli inactivation by cupric ion. Environ. Sci. Technol. 46, 1129911304 (2012). 